\title{
Gallbladder Cancer pN2 TNM Finding v7
}

National Cancer Institute

\section{Source}

National Cancer Institute. Gallbladder Cancer pN2 TNM Finding v7. NCI Thesaurus. Code C90210.

Gallbladder cancer with metastases to periaortic, pericaval, superior mesenteric artery, and/or celiac artery lymph nodes. (from AJCC 7th Ed.) 